\title{
ПРОБЛЕМИ КОМПАРАТИВІСТИКИ
}

DOI: https://dx.doi.org /10.18524/2312-6809.2018.27.146426

УДК $82.0(083.77)$

\section{А. БАРБЮС, Е. РЕМАРК Й О. ГОНЧАР: МАЙСТЕРНІСТЬ АНТИВОЕННОЇ РОМАНІСТИКИ}

\author{
Микола Гуменний, д-р філол. наук, проф., \\ Віра Гуменна, канд. філол. наук, доц.
}

Південноукраїнський національний педагогічний університет

ім. К. Д. Ушинського, м. Одеса

pavlyuknadya@gmail.com

\begin{abstract}
Стаття присвячена дослідженню художньої структури антивоєнних романів А. Барбюса, Е. Ремарка й О. Гончара. Окреслено спільне й відмінне в сюжетно-композиційній основі романів, психології персонажів, портретно-пейзажному аспекті, екстер'єрах та інтер'єрах, авторській мові тощо. Особлива увага акцентується на особливостях їхнього художнього методу - реалістично-натуралістичному (А. Барбюс й Е. Ремарк) і реалістично-романтичному (О. Гончар). При вивченні наскрізних художніх деталей, повторюваних епітетів або однокорінних слів, однотипних тропів, образів-символів, або мовно-жестової поведінки персонажів простежено специфіку художньої структури антивоєнних романів указаних авторів. Крім того, досліджено ключові слова романів, що слугують узагальненими формами образної свідомості, виявлено їх вплив на метафоричну $i$ філософсько-моральну сутність творів. Проаналізовано особливості мовленнєвої структури романів, кваліфікуюча лексика та роль цих форм у тематологічній інтерпретації в руслі авторської позиції.
\end{abstract}

Ключові слова: художня структура, портретно-пейзажний аспект, сюжетно-композиційна основа, відступи - ретроспекції.

В художній структурі антивоєнних романів «Вогонь» А. Барбюса, «На Західному фронті без змін» Е. Ремарка, «Людина і зброя» О. Гончара відтворені закономірності відображеної конкретно-історичної обєктивної дійсності і своєрідність їхнього творчого методу. Відбір воєнних колізій, типізація характерних явищ трагічної епохи, оцінка і характеристика фронтовиків - усе це зумовило художньо-образну систему романів: сюжетно-композиційну основу, психологію персонажів, портретно-пейзажний аспект, екстер'єр та інтер'єр, авторську мову тощо. Власне стильова палітра митців і художні особливості романів можуть бути визначені на основі аналізу взаємодії їх змісту і

(C) Гуменний М, Гуменна В., 2018 
форми. Робота письменників над історичним матеріалом, осмислення ними політичних, соціальних, психологічних, побутових особливостей епохи, створення відповідних характерів, використання поетикальних засобів і виразності підпорядковані вирішенню основного завдання - створити художньо-філософську картину Першої та Другої світових воєн XX століття.

В реалістично-натуралістичному (А. Барбюс й Е. Ремарк) і peaлістично-романтичному (О. Гончар) відображенні історичних подій актуальна воєнна тематика співвідноситься у митців з відтворенням індивідуальних переживань і вчинків персонажів. Особливості їхнього художнього методу - це глибокий психологічний аналіз людських переживань і чітко виражена в повістуванні точка зору авторів на відображені воєнні події, композиційна стрункість, продуманість всього епічного полотна - зумовлюють особливості численних батальних сцен в антивоєнних романах.

Усі спостереження А. Барбюса, Е. Ремарка й О. Гончара як учасників воєнних дій трансформувалися у свідомості Бертрана, Боймера і Колосовського, стали в їхніх антивоєнних романах справжньою трагедією для всього народу. Враження від фронтового життя сприймається ніби своєрідна кінострічка зустрічей, подій і доль, осмислених вказаними персонажами. I в цьому нескінченному потоці з'являються три особи, три характери, найбільш цікаві митцям, люди, чиї думки й погляди повинні стати нашими думками й поглядами. Таким чином синтезуються публіцистичні пласти з емоційно-сподівальними інтонаціями, безпосередньо пов'язані з особистим світом письменників, які відтворили специфічну діаграму душі фронтовика в усіх іiї проявах.

У структурі антивоєнних романів важливу роль відіграють повторення різних типів, що сприяють створенню єдності образу. Це, перш за все, наскрізні деталі, що були об’єктом дослідження деяких критиків (Д. Затонський, М. Гуменний, І. Семенчук) - «Вольпат трусився, і серед ганчірок, намотаних на голову, маленькі очі його хворобливо блищали від лихоманки» [1, с. 63], «Бліде Едорове обличчя хмурніє» [1, с. 101], у Фуйяда «крижаний вітер укриває червоними плямами... засмагле, довгасте обличчя з запалими щоками» [5, с. 127]; Кеммеріх «виглядає... жахливо, кволий, жовтий, на обличчі - якісь чужі риси» [5, с. 41], Бем «сліпий, збожеволівши від дикого болю, він уже не ховався» [5, с. 40], «Губи в нього стали зовсім безбарвні, рот побільшав, 
зуби випинаються, і здається, що вони крейдяні» [5, с. 49]; одна із куль «вдарила в скроню, розтрощила Панюшкіну голову - бризки мозку та крові загусли в його русявому чубі» [2, с. 128], «Дев’ятий обдав його невидячим, помутнілим поглядом. Понурив голову» [2, с. 137], «Лагутін лежав поруч нього блідий, з безтямно закоченими під лоба очима» [2, с. 153]. Зовнішність солдата або його внутрішній стан відтворює низка повторюваних епітетів або однокорінних слів, що надають єдності деяким сценам: «Заклопотаний, темний, блідий, навіжений» [1, c. 30], «божевільний вигляд Кропа» [5, с. 44], «Мюллер волів би краще бігати босоніж по колючому дротові» [5, с. 45], «смертельна небезпека» [2, с. 122], «грузький пісок» [2, с. 122], «холодна райдуга» [2, с. 124] та інші. Повторення, які характерні для однієї теми, можуть виникати і в інших епізодах, вони характеризують не лише персонажа, але й образ - екстер'єр: «бліде небо», «вогненний стовп», «пронизливий вітер», «мулисті мілини» [1, с. 26], «місячне світло» [5, с. 62], «найпотаємніше єство» [5, с. 63], «гарматні постріли», «червонувате світло» [5, с. 65], «зловісні загравища» [2, с. 144], «мертве полум'я» [2, с. 144], «вогняний дощ» [2, с. 148]. Повторення оцінних слів визначають забарвлення окремих фрагментів, відтворюючи погляди певного солдата, його сприйняття воєнних колізій та його товаришів по зброї.

Крім повторів, що концентруються навколо окремого персонажа, в романах широко використовуються повтори слів, що характеризують різних дійових осіб. Наприклад, у зображенні персонажів, митці використовують різноманітні епітети: у Гірлуара «невеличка голова з блідим обличчям» [1, с. 30], Тюлак «високий і кістлявий» [1, с. 31], Самбремез «маленький гладун, чепурний» [1, с. 86], Бем «гладкий, лагідний хлопчина» [5, с. 40], «худющий Тьяден» [5, с. 35], «майор Краснопольский, щуплявий, хворобливий на вигляд чоловік» [2, c. 116], Дев'ятий «кремезний, широкоплечий» [2, с. 132] тощо.

Повторення або однокорінні слова можуть характеризувати й учасників однієї сцени, коли почуття одного солдата або збігаються з почуттями іншого, або передаються йому: «Тірлуар...раптом шаленіє: його лице зморщується, стає злим, кулачки стискуються... - Він божевільний і навіжений, - заявляє Мартро, що має звичку збільшувати виразність своєї думки, вживаючи синоніми» [1, с. 30], «Раптом Тьяденові сяйнула якась думка. Його гостре, наче мишачий писок, обличчя аж засвітилось, очі хитро примружилися, вилиці випнулись і він присунувся ближче: Голубчику, то ти й хліба одержав сьогодні на 
сто п’ятдесят душ, еге? Помідор отетеріло закліпав очима» [5, с. 3637], «...поранений біг, охопивши обличчя так, ніби тримав у руках зрубану голову, і все кричав, ревів нелюдським голосом: «Достреліть! Добийте!...» Так оце вона, війна в своєму справжньому образі! - встиг подумати Колосовський, глибше втискуючись у борозну...» [2, с. 92].

Різних персонажів і сюжетні лінії зближує повтор слів, що належать до одного семантичного поля. Літературні критики відзначали, що душевний стан персонажів передається метафорами, зв’язаними темою війни, обстрілів і страждань: «...ми повертаємось у конуру, де живемо. Ії̈ зворушлива простота хвилює мені душу, безліч душ. Досить було показатися сонцю, відчути на собі його проміння й влаштуватися трохи зручніше, як повне страждань минуле для нас більше не існувало, і жахливе майбутнє теж... «Нам тепер добре,» - і край» [1, с. 89], «На брустверах, у сховищах, скрізь, де ї зненацька заскочила смерть, стояли і лежали люди з синіми обличчями...» [5, с. 122], «Степурині рани теж розболілись, печуть. Провалившись до борту кузова, він зціплює зуби, щоб не застогнати, коли машина гуцає. При кожнім такім ударі він почуває свої порвані атлетичні м'язи на ногах, всі осколки, що, як залізні остюки, позастрявали йому в тілі» [2, с. 160].

В єдиному образному аспекті відображаються й різні прояви людського життя під час війни. Контрастні сцени - почуття любові між Маріеттою й Едором (він загинув), між Мар'яною і Лагутіним (його було вбито), у Ремарка почуття любові простежується лише на рівні флірту - співвіднесені не лише тематично, композиційно, але й образно. Ці образи пов'язані не тільки один з одним, але й зі своїм найближчим оточенням і мають дотичність до відповідних реалій війни. Правий дослідник, стверджуючи, що «звернення до тієї чи іншої теми свідчить про певну ідеологічну позицію автора...» [4, с. 100].

Різних персонажів об'єднує наскрізний мотив, який має пряме вираження - мотив смерті, загибелі. 3 його розвитком пов'язана не тільки сюжетна лінія Ламюза, Едора, Гуньяра, Барб’є, Годфруа, Кеммеріха, Качинського, Боймера, Лагутіна, Степури, Духновича, хоча тут іiї вираження найбільш очевидне. Цей мотив виникає й у відношенні до інших персонажів: Вольпата, Параді, Тірета, Кропа, Левандовського, Колосовського, Колумба та ін. Таким чином, різні воєнні ситуації оцінюються поліаспектно.

Визначені смислові ознаки виявляються єдиними для різних персонажів романів. Змінюється лише міра інтенсивності їх проявів і ха- 
рактер їх розподілу між діючими особами. При всій своїй визначеності персонажі романів виявляються відкритими.

Повтори визначають не лише ставлення персонажів одного до іншого, але й відношення їх до навколишнього світу. Повтори знаходяться в основі одного із типів тропів - порівняння або метафори, відштовхуються від реалій, що мають самостійну значушість у художньому світі і творів. За допомогою порівняння такого типу персонаж зіставляється з предметним світом, що його оточує. Однотипні тропи мають різне походження і різне призначення в текстах. Одні з них виникають безвідносно до характеру відтворюваного трагічного світу, інші ніби виростають із цього світу. Деякі порівняння, що не мають домінантного значення у вузькому контексті мають наявну функціональність у широкому. Але у всіх випадках солдати (у Барбюса і в Ремарка) ідеалізують почуття товариськості як і стоїки в античні часи [6, с. 137]. Адже їхня позитивна програма була дещо обмеженою вони протиставляли фронтову дружбу жорстокій війні.

Цілком закономірна для антивоєнних романів А. Барбюса, Е. Ремарка й О. Гончара змістовна наднасиченість порівнянь, метафор, художніх деталей, які, як правило, слугують своєрідним мікрокосмом цілого. Органічно властиву здатність «синтезувати» реальність, доводити образ до такої міри концентрованості, коли на самому елементарному рівні вже вгадуються значні аспекти воєнного часу, навряд чи можна пояснити, не звертаючись за допомогою до такого поняття, як символ. Це тим більше стосується так званих «наскрізних образів» в аналізованих романах, що виконують різноманітні функції, але до певної міри зберігають постійність, символічність значень. Серед таких образів-символів можна назвати такі, як кров, обстріли, смерть, поранення, що виникають як символи в реальних умовах війни, що дозволяють зробити висновок про надзвичайне значення цієї символіки в ідейно-художній системі романів.

В антивоєнних романах указана символіка детермінована не лише ідейно-тематичним аспектом, але й реалістичними образами й деталями, які ні в чому не відступаючи від принципів реалізму, вбирають у себе символічні ознаки. Сама ідея реалістичного функціонування символу в художній системі А. Барбюса, Е. Ремарка й О. Гончара, на нашу думку, належить Б. М. Ейхенбауму, але цілком можливо, що цей процес вбирає в себе значно більше коло художніх явищ, ніж прийнято вважати. Адже вказані образи-символи детерміновані конкрет- 
но-історичними обставинами війни, iї трагічними колізіями та чорно-сірою кольористикою, що втягує в зону символічного впливу цілу низку деталей, які зумовлюють рівень реальності. Потужний символічний заряд, втілений в образах-символах, має постійну тенденцію до розширення.

Доцільно розглянути деякі особливості взаємозв'язку образів-символів «поранення», «крові», «смерті», а також епітетів «чорний», «сірий» в антивоєнних романах. Образ «крові» часто повторюється в контексті, поглиблюючи тему смерті: «...незважаючи на втому, що пригнічує їх, і на зовсім недавню різанину, що забризкала їх кров’ю, незважаючи на загибель їхніх братів ... вони святкують своє врятування» [1, с. 63], у Годфруа «вирвало всю середину тіла. Він умить зійшов кров’ю на місці...» [1, с. 61], «Ефрейторові, що біг поруч зі мною, відірвало голову. Він пробіг ще кілька кроків, а в нього з шиї дзюрком б’є кров» [5, с. 96], «...поранені хапають нас за ноги і кричать, коли ми через них перестрибуємо» [5, с. 97], «Степура ... як і раніш, лежав на своєму місці, весь підпливши кров'ю» [2, с. 249]. Описи крові в багатьох сценах безпосередньо пов’язані з темою страждань і смерті. Уже 3 перших сторінок романів образ «поранення» формує два основних мотиви - життя і смерті. 3 розгортанням сюжету образи-символи «крові», «поранення», «обстрілів» стають постійними атрибутами текстів, являючись своєрідним матеріальним втіленням світла-тьми.

Персонажам романів необхідно фактично пройти через «два життя» - уявне й істинне - і відповідно пережити (щоправда не всім вдається) «дві смерті» - фізичну і духовну. Відображення цього процесу помічаємо і в сюжетно-композиційній структурі романів, на сторінках яких відтворено складну діалектику людських страждань, переживань, роздумів і досить часто фізичну смерть фронтовиків. Іншими словами, уже композиція орієнтує на можливість символічного прочитання текстів.

Використання епітета «сірий» можна розглядати як своєрідний кольоровий символічний ряд, шо тісно пов'язаний з іншим символічним рядом, створеним за допомогою епітета «чорний»: «світло-сірі мундири» [1, с. 49], «чорні лакові чоботи» [1, с. 49], «сірим небом» [1, с. 59], «сіруватий світанок» [1, с. 59], «темна хмара» [1, с. 59], «світло-сіре покривало» [1, с. 72], «темно-руда фарба» [1, с. 141], «сіра земля» [5, с. 189], «синьо-чорна грязюка» [5, с. 42], «чорні губи» [5, с. 105], «чорний обрис лісу» [5, с. 100], «темна ніч» [2, с. 145], «чор- 
ний автомат» [2, с. 146] та інші. В результаті ми маємо об'єднаний сприйняттям наратора потік зовнішніх вражень (зорових, слухових, дотикових), несподіваних асоціацій досягнутих здебільшого шляхом персоніфікації. Тут виразно простежується відчутний для імпресіоністичної поетики синтез чуттєвих вражень.

В аналізованих романах значну роль відіграють кольорові епітети, що сприймаються поряд з іншими деталями і образами одночасно у двох планах - конкретному і символічному, які, власне, виконують основне змістове навантаження. Наприклад, Е. Ремарк ніби стягує функціональність чорного кольору до фінальної кінцівки роману, коли рядовий Боймер гине. Але цей образ невіддільний від наскрізного образу-символу війни, який, починаючи із самої назви і закінчуючи розв'язкою (сцена смерті), слугує символічним вираженням основного конфлікту і власне визначає трагічний пафос роману. В романі ж А. Барбюса спостерігаємо рівномірну поліфункціональність кольорових епітетів: в описах екстер'єрів, в портретних характеристиках і в авторських відступах. Усі перераховані поетикальні атрибути підпорядковані розкриттю ідейно-тематичної основи роману і психології персонажів. Роман А. Барбюса «Вогонь», пронизаний внутрішнім ліризмом, поєднує високу змістовність з філігранною обробкою кожної художньої деталі. Заангажовані літературні критики не могли зрозуміти, що в романі відображення людей і воєнних ситуацій і висновки, що напрошуються з цього відображення, наскрізь соціальні. У романі ж О. Гончара наявне поєднання воєнних сцен і розгорнуте життя народу в тилу. В романі відтворені маштабні контрасти - воєнного і тилового життя людей. Але засоби художнього створення образу - портрет, опис обставин, діалоги, сцени, кольорові епітети, порівняння, метафори, авторська характеристика насичені в антивоєнних романах глибоким психологічним змістом. Тут доречно погодитись із думкою дослідника, що «колір ізоморфно перетворюється в сигнал нової інформації - почуттєвий, у новий образ, який здатний викликати, перш за все, приємне або неприємне почуття, почуттєву оцінку певного явища, події, факту, предмета чи обставини» [3, с. 299].

Пейзаж, інтер'єр зазвичай подаються у сприйнятті внутрішнього мовлення персонажів і не порушують загального характеру структури оповідності художнього тексту (являючись однією з різновидів репродуктів). 
Якщо підійти до повістувального художнього тексту з погляду мовленнєвої взаємодії автор-персонаж, то в якості об'єкта дослідження неминуче будуть виступати способи акцентування на мовленні персонажів, а точніше, на мовно-жестовій поведінці діючих осіб, оскільки інформація про мовлення персонажів (в ії вербальному і невербальному вираженні) органічно пов’язана з інформацією про їх емоційний та психологічний стан, діях, вчинках, обставинах (найбільшою інтенсивністю в указаному поетикальному аспекті відзначається роман А. Барбюса, дешо менше - роман Е. Ремарка і зовсім незначною мірою - роман О. Гончара).

В романах указаних авторів помічаємо, що в аналітичних формах авторські інтенції виражені більш чітко. Тут подаються вказівки на вербальну мовленнєву поведінку (жест, міміку, інтонацію, емоційний стан), немовленнєву поведінку (дії, вчинки), що вступають у певні відношення з вербальним мовленням. Подаються також вказівки на обставини мовлення і дії, на наявні різного роду мотивування, кваліфікації й оцінки (інколи прямі оцінювання).

Заслуговує на увагу така особливість мовленнєвої структури романів, як внутрішнє мовлення-сприйняття солдатів. Звертає на себе увагу значна питома вага внутрішнього мовлення персонажів у мовленнєвій і взагалі художній структурі романів. Усі події пропущені через призму свідомості фронтовиків. В їх сприйнятті і внутрішньому мовленні подані пейзаж, портрет, побутові деталі тощо. Найбільш вживаним є «приховане» внутрішнє мовлення-сприйняття, що поєднане з авторською мовою. Воно вводиться в текст, як правило, дієсловами на означення сприйняття і почуттєвості: підходить, лається, скаржиться, зморшується [1, с. 30], зупиняється, свистить, розтерти, забрати, дивується [5, с. 192], добувають, виконувати, підводиться, кинулись, розкладалися [2, с. 136].

У тісному зв'язку із внутрішнім мовленням знаходяться багатоаспектні функції слів у складній мовленнєвій архітектоніці аналізованих романів. Звертає на себе увагу лексика, що грунтується на предметно-змістових і оцінних аспектах. В основному це слова, експресивний характер яких невіддільний від їх значення. В той же час окресленість реалістичних художніх характеристик, особлива повнокровність відображення створюється завдяки гострому індивідуальному переосмисленню емоційно-експресивних елементів, що стійко зв'язані зі словом у мові. 
У використанні оцінної лексики в А. Барбюса, Е. Ремарка й О. Гончара спостерігаємо зіткнення протилежних типів оцінок, яке підпорядковане і в пейзажі, і в оповіді про воєнні події, і в системі образів розкриттю ідейно-художньої концепції романів. У сферу оцінності потрапляє лексика з так званою «асоціативною ефективністю»: виразні, оцінні ії якості базуються на здатності викликати уявлення про ті чи інші форми життя і діяльності.

Кваліфікуюча лексика набуває більшої ваги і психологічної значущості в описах виразу обличчя персонажа. Слова з оцінним значенням, що характеризують погляд того чи іншого персонажа, вираз його обличчя як найбільш важливу особливість його душевного складу, вводяться митцями при особливій напрузі, актуалізації стилістичних засобів, при порушенні так званого «ефекту очікування», що створює відповідний ритм змістового центру тексту: «Обличчя залишаються сірі й чорні: можна подумати, що вони не в силі видертися 3 нічних обіймів і що ніколи не пощастить позбутись їх» [1, с. 70]; «Верхня частина... тулуба стоїть, прихилившись до стіни, обличчя лимонно-жовте...» [5, с. 104]; «Сірі очі великі, обличчя широке, суворе, в ранніх зморшках» [2, с. 245].

Розвиток думки в аналізованих романах здійснюється через тематологічну інтерпертацію, через зіткнення характерів і воєнних ситуацій, оцінок, думок, висновків. У групуванні персонажів, подій, відображення внутрішнього життя персонажів спосіб протиставлення має безмежні можливості. Зіткнення різних сил організує оповідь на всіх його рівнях. Найбільш плідним в осягненні секретів майстерності вважаємо шлях від художнього тексту до концепції, а від концепції до тексту, до закону стилю, якому підпорядковане все.

Отже, структура письменницької думки відчувається у творі на всіх його рівнях. Авторська думка то з'єднує частини в єдине ціле, то ділить ціле на окремі частини. В результаті цього виникає подвійна структура оповіді, вона виражає різноспрямований хід думок і почуттів героїв. Створивши модель стану людини на війні, внутрішнє єство якої визначається зіткненням протилежних життєвих обставин, митці досліджують складний психологічний аспект.

Ми вже писали про традиції А. Барбюса, Е. Ремарка й О. Гончара, але ставити спільний принцип організації структури романів указаних митців у залежність від певних традиційних орієнтирів було б несправедливо по відношенню до них. Ситуації Першої та Другої світових 
воєн, що склали основу аналізованих романів, - ситуації грандіозного світового конфлікту, в якому зіткнулися політика, економіка і мораль...

У глибині дослідження людського життя на війні, в його єдності з життям народу полягає одна із найхарактерніших і найбільш важливих особливостей реалізму авторів антивоєнних романів. Ця особливість переконливо проявляється і в принципах сюжетобудови в них. У тих випадках, коли складна політично-етична і філософсько-історична система ідей не могла бути реалізована в характерах героїв, вона знаходила вираження в романах у позасюжетних елементах оповіді. Авторські відступи, філософські чи етичні роздуми складають суттєву сторону композиції аналізованих романів.

У структурі антивоєнних романів знаходимо авторські відступи-ретроспекції, в яких йдеться про певний період життя героїв: «Там він народився, ріс, був щасливий і вільний. Він бавився там на золотистій, рудуватій землі, грався навіть у солдатів. Запал, з яким він вимахував дерев'яною шаблюкою, наливав рум'янцем його кругленькі щоки, шо тепер геть позападали, пожовтіли й немов укрилися шрамами...» [1, с. 130]; «Нас, дітлахів, тополі чимось прваблювали, і ми цілісінькі дні проводили біля них, слухаючи тихий шелест листя. Ми сиділи під ними на березі річечки, звісивши ноги в ії̈ прозорі квапливі хвилі. Свіжий дух води і мелодія вітру в верховіттях тополь оволодівали нашою уявою» [5, с. 99]; «Крізь тисячокілометрові завії снігів, скрізь фронти, крізь рублені стіни казарми приходить до нього з тієї польової доріжки вона» [2, с. 351].

В текстових фрагментах романів помічаємо конкретні ілюстрації нових авторських принципів співвідношення суб'єктивних і об'єктивних елементів стилю. Тут, перш за все, відтворюються довоєнні згадки героїв про суттєві епізоди їхнього життя. Саме відображення здійснюється з погляду суб'єкта-персонажа з помітною авторською експресією (особливо в О. Гончара вона проявляється в романтично-ліричному аспекті), де оцінні спогади і характеристики несуть суб'єктивне забарвлення.

Повістування, навіть коли воно не зв'язано з тією чи іншою персоніфікованою формою (в А. Барбюса - щоденник і листування, в О. Гончара - листування і спогади оповідача, в Е. Ремарка - спогади оповідача), завжди виражає погляди оповідача. Розповідаючи про воєнні події митець, як би він не прагнув до об'єктивного, епічного відображення життя, завжди вносить у оповідь своє трактування, 
своє розуміння й оцінку відтворених явищ, завжди надає об'єктивній оповіді своє бачення.

Оповідь в антивоєнних романах супроводжується авторськими ремарками, коментарями, що захоплюють увагу читача до таких сторін явища, подій чи життя солдата. Вона безпосередньо розкриваються не лише у вчинках та його діях, але й у тих узагальненнях, трактуваннях, характеристиках, які дає оповідач відображеному явищу або переживанню.

Композиційна роль автора в розвитку сюжетної системи антивоєнних романів значна і різноманітна, об'єктивне і суб'єктивне іiї розуміння сприяє з'ясуванню своєрідності художньої майстерності митців. Принцип життєвої правди виявляється домінуючим у створенні письменниками сюжетної системи своїх романів (А. Барбюс опублікував свій роман по гарячих слідах війни у 1916 році, Е. Ремарк - у 1929 році, О. Гончар - у 1959 році). Хронологія створення їхніх романів свідчить про те, що письменники мали у своєму розпорядженні різні часові можливості для художнього й філософського осмислення жахливих подій війни (звичайно, тут слід враховувати й рівень їх таланту). В розкритті народної теми значну роль відіграє оповідач, який пояснює справжній сенс воєнних подій і значення діяльності народних мас.

Відтворюючи людські характери в усьому різномаїтті їх життєвого прояву, автори знаходять саме ті мовленнєві форми, що найкраще відповідають різним сферам життєдіяльності людини на війні. Майстерність письменників полягає в тому, що вони вміють відбирати із багатого лексичного і синтаксичного запасу саме ті слова і звороти, що передають психологію й провідні риси характерів їх персонажів.

\section{СПИСОК ВИКОРИСТАНИХ ДЖЕРЕЛ}

1. Барбюс А. Вогонь / Анрі Барбюс. - К. : Молодь, 1974. - 303 с.

2. Гончар О. Твори: в 7 т. / Олесь Гончар. - К. : Дніпро, 1987. - Т. 4. - 589 с.

3. Гуменний М. Західний антивоєнний роман і проза О. Гончара: компаративний аспект : монографія / Микола Гуменний. - Вид. др., доп. - К. : Євшан-зілля, 2012. - 376 с.

4. Дима А. Принципы сравнительного литературоведения / Александр Дима. - М. : Наука, 1977. - 229 с.

5. Ремарк Е. М. Твори : у 2 т. / Еріх Марія Ремарк. - К. : Дніпро, 1986. T. $1 .-573 \mathrm{c}$.

6. Чанышев А. Н. Курс лекций по древней и средневековой философии / А. Н. Чанышев. - М. : Высшая школа, 1991. - 512 с. 


\title{
А. БАРБЮС, Э. РЕМАРК И О. ГОНЧАР: МАСТЕРСТВО АНТИВОЕННОЙ РОМАНИСТИКИ
}

\author{
Николай Гуменный, д-р филол. наук, проф., \\ Вера Гуменная, канд. филол. наук, доц. \\ Южноукраинский национальный педагогический университет \\ им. К. Д. Ушинского, г. Одесса
}

\begin{abstract}
Статья посвящена исследованию художественной структуры антивоенных романов А. Барбюса, Э. Ремарка и О. Гончара. Выделены общее и отличительные особенности в сюжетно-композиционной основе романов, психологии персонажей, портретно-пейзажных описаниях, экстерьерах и интерьерах, авторской речи и тому подобное. Акцентируется внимание на особенностях их художественного метода - реалистически-натуралистическом (А. Барбюс и Э. Ремарк) и реалистически-романтическом (О. Гончар). При изучении сквозных художественных деталей, повторяющихся эпитетов или однокоренных слов, однотипных тропов, образов-символов или языково-жестового поведения персонажей прослежено специфику художественной структуры антивоенных романов указанных авторов. Кроме того, исследованы ключевые слова романов, которые служат обобщенными формами образного сознания, а также отмечено их влияние на метафорическую и философско-моральную сущность произведений. Исследуются также особенности речевой структуры романов, квалификационная лексика и роль этих форм в тематологической интерпретации в русле авторской позиции.
\end{abstract}

Ключевые слова: художественная структура, портретно-пейзажный аспект, сюжетно-композиционная основа, отступления - ретроспекции.

\section{A. BARBUSSE, E. REMARK AND O. GONCHAR: SKILL ANTI-WAR ROMANCE}

\section{Mykola Gumennyj, Vira Gumenna}

\author{
South Ukrainian National Pedagogical University named after K. D. Ushinsky, \\ Odessa, Ukraine
}

The article is devoted to the study of the artistic structure of anti-war novels by A. Barbus, E. Remark and $O$. Gonchar. The general and distinctive features in the plot-compositional basis of the novels, psychology of the characters, portrait-landscape aspect, exteriors and interiors, author's speech and so on are allocated. A special attention is paid to the peculiarities of their artistic method, such as realistic-naturalistic (A. Barbus and E. Remark) and realistic-romantic (O. Gonchar). In the study of cross-cutting artistic details, repeated epithets or words of the same root, the same type of tropes, images, symbols or language-gesture behavior of the characters traced the specifics of the artistic structure of the anti-war novels of these authors. In addition, the key words of the novels, which serve as generalized forms of figurative consciousness, as well as their influence on the metaphorical and philosophical-moral essence of the works, are studied. The features of the speech structure of the novels, qualification vocabulary and their role in the thematic interpretation in line with the author's position are also studied. The images-symbols, 
which are determined by the specific historical circumstances of the war, its tragic collisions and black-and-gray coloristic, which draws into the zone of symbolic influence of the row of details that determine the level of reality, are characterized in the article. The process of combining of the journalistic layers with emotional-confessional intonations directly related to the personal world of the writers who recreated a specific diagram of the soldier's soul in all its manifestations is studied. It is traced that in the analyzed novels the significant role is played by the color epithets, which are perceived along with other details and images simultaneously in two plans - concrete and symbolic, that perform the main semantic load.

Key words: art structure, portrait-landscape aspect, plot-compositional base, retrospective indentations.

\section{REFERENCES}

1. Barbius, A. (1974), Vohon, Molod, Kyiv [in Ukrainian].

2. Honchar, O. (1987), Tvory (Vol. 1-7), Vol. 4, Dnipro, Kyiv [in Ukrainian].

3. Humennyi, M. (2012), Zakhidnyi antyvoiennyi roman i proza O. Honchara: komparatyvnyi aspekt, Vyd-vo «Ievshan-zillia», Kyiv [in Ukrainian].

4. Dyma, A. (1977), Pryntsypы sravnytelnoho lyteraturovedenyia, Nauka, Moscow [in Russian].

5. Remark, E. M. (1986), Tvory (Vol. 1-2), Vol. 1, Dnipro, Kyiv [in Ukrainian].

6. Chanyshev, A. N. (1991), Kurs lektsyi po drevnei y srednevekovoi fylosofyy, Vysshaia shkola, Moscow [in Russian].

Стаття надійшла до редакції 30 березня 2018 р. 